\title{
EPIDEMIOLOGY AND CONTROL OF GENITAL PASTEURELLOSIS IN BREEDING RABBITS
}

\author{
Moshira. A. El-Abasy ; Amany. M. Taha ${ }^{* *}$; Rowida, M. Riad ${ }^{* *}$; Amal, A. M. \\ Ghoneim $^{* * *}$ and El-Gohary, A. A. . \\ *Department of Poultry Diseases, Fac. of Vet. Med., Kaferelsheikh University \\ *** Department of Artificial insemination and embryo transfer, A.R.R.I, Giza. \\ *** Department of Microbiology, A.R.R.I, Giza.
}

\begin{abstract}
ABESTRACT
This study aimed to investigate the epidemiology and the possible ways of control of Pasteurella multocida (P. multocida) microorganism as a genital and a respiratory pathogen in rabbit bucks during the period from 2012-2016. Two hundred semen and nasal samples randomly collected from 23-35-week-old apparently healthy breeding bucks representing 30 rabbit farms located in different districts at Giza Governorate. The examined rabbit bucks suffered from low reproductive activity. Serological identification was performed by using slide agglutination test (SAT), gel-diffusion precipitin test (GDPT) and enzyme linked immunosorbant assay (ELISA). Molecular identification of the isolated strains was performed using polymerase chain reaction (PCR). The correlation between the presences of $P$. multocida and reproductive disorders in rabbit bucks was investigated by measuring semen parameters (advanced sperm motility \%, live spermatozoa \%, Sperm concentration $\times 10^{6} / \mathrm{ml}$ and sperm abnormalities \%) in alternative husbandry systems. The results revealed that isolation of 7 isolates of P. multocida with an incidence of $3.5 \%$. The in vitro antibiotic sensitivity test revealed that the isolated strains were highly sensitive to thiamphenicole, gentamycin, ciprofloxacin, amoxycillin, amoxycillin + clavulanic acid, clindamycin, colistin sulphate,
\end{abstract}


tetracycline, enrofloxacin, lincomycin and vancomycin and moderately sensitive to neomycin and oxytetracycline. On the other hand isolates were resistant to ampicillin, erythromycin, penicillin $G$, sulphamethozole-trimethoprim and streptomycin. Experimental infection of 6-8-month-old rabbit bucks with isolated strain (A: 12) of $P$. multocida from semen followed by treatment trials using thiamphenicole and gentamycin with ciprofloxacin were carried out. Clinical signs, postmortem gross lesions and semen evaluation with re-isolation of $P$. multocida strains in pure form were discussed in details. Histopathological examination of tissue sections from different organs of experimentally infected bucks revealed less severe lesions after treatment with thiamphenicole and gentamycin with ciprofloxacin, when compared with infected non treated rabbit groups.

Keywords: Genital Pasteurellosis, rabbit bucks, bacteriology, semen evaluation, experimental infection, histopathology, treatment.

\section{INTRODUCTION}

Currently, rabbit industry has a special attention in Egypt as the main animal for high quality meat and fur production. Pathogen free semen is essential for natural or artificial insemination. Infertility in rabbits represents one of the major problems that threaten rabbit reproduction and production (AbdEL-Ghaffar, 1992).

Pasteurellosis is one of the most feared bacterial diseases of rabbits. The disease is often made worse by errors in rabbit breeding management that facilitate the action of opportunistic bacteria as Pasteurella spp., of which rabbits are often a symptomatic carriers and the infection can't be fully controlled by antibacterial treatments (Casalinuovo et al., 2013). 
P. multocida is a Gram negative bacterium infects a wide range of animal species, causing snuffles, haemorrhagic septicemia, endometritis, pyometra, orchitis and epididymitis, S/C absecess, conjunctivitis and otitis media in rabbits (Lebdah, 2010). P. multocida infection diagnosis is based on clinical signs, postmortem findings and the isolation and identification of the organism from infected rabbit tissues by cultural and biochemical characteristics (Glisson et al., 2003).

There are some kinds of antibiotics routinely added to the semen used for artificial insemination to control contaminants (Kuster and Althouse, 2016). The present study shed the light on the use of three types of antibiotics (to which P. multocida is sensitive and examine their effects on diluted semen and when used single and in combination at different concentrations.

The objective of the present study was to investigate of the prevalence of $P$. multocida among male rabbit bucks and its effect on the reproductive performance and how to control this disorder through using of treatment trials of the experimentally infected rabbit bucks.

\section{MATERIALS AND METHODS}

\section{Samples:}

Semen samples and nasal swabs were collected from 200 apparently healthy breeding bucks in 30 different rabbit farms at 23-35week-old, located in different districts at Giza Governorate during the period from 2012-2016. Rabbit bucks were S/C+ vaccinated with $1 \mathrm{ml}$ formalized polyvalent rabbit Pasteurellosis vaccine at 2-month-old , $2 \mathrm{ml}$ at 4 months of age then repeated every 3 months and $0.5 \mathrm{ml}$ of inactivated rabbits haemorrhagic disease virus (RHDV) was S/C injected at 2-month-old then repeated every 6 months. Breeding rabbits had low reproductive activity. 


\section{Specimens' collection:}

Three hundred semen samples, 300 lungs, 100 heart, 100 liver, 100 testes and 100 epididymes were collected from apparently healthy rabbit buck farms. Samples were collected from sacrificed rabbits from different farms located at different districts in Giza Governorate for $P$. multocida isolation. Semen samples were collected for semen evaluation. Testes, lungs, heart and liver tissue samples were taken from experimentally infected rabbit bucks for histopathological examination.

\section{Semen collection:}

Semen samples for semen evaluation (advanced sperm motility\%, live $\%$, Sperm concentration $x 10^{6} / \mathrm{ml}$ and sperm abnormalities $\%$ ) were collected from apparently healthy bucks under aseptic condition three times per week before inoculation according to the method described by Evans and Maxwell (1987) which proved to be normal semen characteristics ( initial progressive motility not less than $70 \%$ ). After inoculation by $P$. multocida, semen samples were collected from bucks during the period of experiment three times weekly for six weeks. After scarification of bucks, semen samples were collected from caudal epididymis and diluted (1:1) immediately with warmed $\left(37^{\circ} \mathrm{C}\right) 0.9 \%$ $\mathrm{NaCl}$ for evaluation according to Reynolda et al. (1989).

\section{Bacterial isolation:}

A Loopfull of each sample was inoculated into brain heart infusion broth and incubated at $37^{\circ} \mathrm{C}$ for 24 hours. A Loopfull was taken from incubated broth culture and streaked on dextrose starch agar containing $5 \%$ normal chicken serum, incubated at $37^{\circ} \mathrm{C}$ for 24 hours then subculture on $10 \%$ sheep blood agar, MacConkey's agar, nutrient agar and tryptic soy agar and examined for suspected P.multocida colonies then subcultured to obtain pure colonies. Colonies were examined for colonial morphology (shape, size, colour, appearance, odor and 
elevation), films were prepared from the suspected pure colonies and samples, stained with Gram's and Giemsa stains to be examined microscopically under oil emersion lens (Cruickshank et al. 1975). Biochemical identification of the isolated strains was performed using API 20 NE strip (Bio-Merieux, Lyon, France).

\section{Serological identification:}

a. Slide agglutination test was performed on the isolated P. multocida strains using diluted antiserum (kindly provided by Animal Health Research Institute, Kafrelsheikh Branch) according to Nawaz et al. (2006).

b. Gel- diffusion precipitin test (GDPT) was performed on the isolated $P$. multocida strains according to Heddleston et al. (1972).

c. The commercial P. multocida ELISA kits (Glory Science Co., Ltd, China Manufactureres, China) were used for rapid serological identification of such pathogen according to and Ashraf et al. (2014).

\section{Molecular identification (PCR):}

1. Reagents used for agarose gel electrophoresis:

a. Agarose powder, Biotechnology grade $\left(\right.$ Bioshop $^{\mathrm{R}}$, Canda inc. lot No: OE16323): It prepared in concentration $2 \%$ in $1 \times$ TAE buffer.

b. Tris acetate EDTA (TAE) electrophoresis buffer (50xliquid concentration) $\left(\right.$ Bioshop $^{\mathrm{R}}$, Canada inc. lot No: 9E11854): The solution diluted $1 \times$ by adding $1 \mathrm{ml}$ stock solution to $49 \mathrm{ml}$ double distaled water to be used in the preparation of the gel or as a running buffer

c. Ethedium bromide solution (stock solution) biotechnology grade (Bioshop $®$ Canda Inc, Lot No: 0A14667): The stock solution was diluted by $25 \mu 1 / 200 \mathrm{ml}$ double distilled water and stored covered at $4^{\circ} \mathrm{C}$. It was used for staining of PCR products that electrophoreses on agarose gel to be visualized by UV light. 
2. Gel loading buffer (6xstock solution) (Fermentas, lot No: ooo56239). The components were dissolved in sterile double distilled water and stored covered with aluminum foil at room temperature.

3. DNA ladder (molecular marker):100 bp (Fermentas, lot No: 00052518).

4. 5X Taq master (Fermentas): containing polymerase enzyme, Magnesium chloride $\left(\mathrm{Mg} \mathrm{Cl}_{2}\right)$,

Deoxy nucleotide triphosphate (d NTP) and PCR grade water.

5. Primer sequences of $P$. multocida used for PCR identification system: Table (1).

6. DNA preparation from bacterial culture was performed according to Antony et al., (2007).

7. DNA amplification was performed on a Thermal Cycler (Master cycler, Eppendorf, Hamburg, Germany) according to Townsend et al. (1998)

\section{Antibiogramme:}

The in vitro antibiotic sensitivity test of isolated $P$. multocida strains was investigated against 19 different antimicrobial agents using the disc diffusion technique according to Cruick-Shank et al. (1975).

\section{Experimental infection:}

A total of 54, 6-8-months-old, mature apparently healthy rabbits (45 bucks and 9 does) obtained from rabbit farms located in Giza Governorate, free from $P$. multocida infection by insertion of cotton swabs into nares, semen samples (part for evaluation of its parameters and the second part for laboratory investigation) and genitalia of does and inoculated in pepton broth at $37^{\circ} \mathrm{C}$ for $24 \mathrm{hrs}$ then streaked on Dextrose starch agar sheep, blood agar and MacConkey's agar and incubated at $37^{\circ} \mathrm{C}$ for $24 \mathrm{hrs}$. Rabbits were reared, fed on antibiotic free ration and randomly divided into nine groups (five bucks and one doe 
each). Serial dilution of $P$. mulocida cultured on brain heart infusion agar plates, $1 \times 10^{8} \mathrm{CFU} / \mathrm{ml}$ was administrated as shown in Table (2). Rabbits kept for 1 week pre-infection to ensure that they were free from $P$. multocida infection, and for 6 weeks post infection. The number of dead rabbits, signs, postmortem and histopathological lesions were recorded.

\section{Treatment Trials:}

Based on the result of the in vitro antibiogramme, thiamphenicole $1.25 \mathrm{ml} / \mathrm{L}$ drinking water for 5 consecutive days used for treatment of 3 rabbit groups, mixture of gentamycin $(0.1 \mathrm{ml} /$ head $)$ injection + ciprofoxacine $0.25 \mathrm{ml} / \mathrm{L}$ drinking water for 5 consecutive days used for treatment of 3 groups and the remained 3 groups kept without treatment till the end of the experiment. The treatment trials started on the $7^{\text {th }}$ day PI after appearance of clinical signs. Experimentally infected and treated rabbits were kept under observation for 7 weeks PI during which clinical signs, P.M findings, semen evaluation with re-isolation of the infected organism were carried out.

\section{Histopathological examination:}

Specimens of testis, lung and heart were collected from sacrificed experimentally infected rabbit bucks (pre-infection and post-infection) and fixed in $10 \%$ formol saline, (dehydrated in different concentrations of alcohols, cleared in xylol and embedded in paraffin), sectioned at 3$4 \mu \mathrm{m}$ and stained by hematoxylin and eosin stain for histopathological examination (Bancroft and Stevens, 1990).

\section{Statistical analysis:}

Statistical analysis of the obtained data was carried out using SPSS Program, Kruskal Walli test is a non parametric test used for comparison between more than 2 groups in a quantitative variable and Friedman chisquared test is a non parametric test used for comparing repeated measures of a quantitative variables in the same group. $P$ value represents the level of significance when it is less than 0.05 this denotes statistically significant difference. 


\section{RESULTS AND DISCUSSION}

The field reports describing apparently healthy rabbit bucks at the same period parallel with low reproductive performance which were collected randomly from 30 rabbit farms at 23-35-week-old. The isolation rate of P. multocida was $3.5 \%$ (7 out of 200) Table (3). The low rate of isolation may be due to the routine vaccination against this bacterium and the isolation was done on apparently healthy rabbits. Similar results were obtained by Rendondo et al. (1990), Merciers (1992), Nada (1994) and Virág et al. (2008) who reported that the carrier rate of $P$. multocida among normal rabbits in the upper respiratory tract was 2-3.9\%. Moreover Nada (1994) reported that the isolation rate of $P$. multocida was $9.1 \%$ among affected rabbits while $\boldsymbol{E l}$ Tayeb et al. (2004) reported death of $50 \%$ of the adult clinically diseased rabbits which was removed from production due to infection by $P$. multocida, which represented a major economic loss.

Concerning the prevalence of $P$. multocida in the internal organs and semen, the isolation rate was higher $2 \%$ (6 out of 300) from lungs than that of the semen which was $0.33 \%$ (1 out of 300 ). But the isolation rate was zero from testes, epididemes and heart (Table 4). Similar results were obtained by Selim et al. (1998) and Casalinuovo et al. (2013) when isolated $P$. multocida from genital and respiratory swabs and decided that semen has a role in the spread of the infection. While Virág et al. (2008) isolated P. multocid from heart blood in most cases.

Morphological identification of the isolated P. multocida strains revealed that the colonies appeared as smooth, convex, translucent, and dewdrop like on sheep blood agar Fig. (1), irridesecent with pearl like appearance on dextrose starch agar media Fig. (2) and no growth on MacConkey's agar. Similar results were obtained by Roades and Rimler (1987). 
Our results revealed that colonies were non haemolytic on blood agar plates. Generally P. multocida has been considered as a nonhaemolytic bacterium while Lee et al (1990 and 1991) already noticed lysis of erythrocytes by $P$. multocida.

Microscopical examination of Gram stained smears of suspected colonies showed Gram negative bipolar bacilli or cocobacilli, non spore forming and capsulated arranged singly, in pairs, and occasionally as chains or filaments. Similar findings were reported by (Calnek et al., 1997).

Biochemical identification results revealed that $P$. multocida isolates were oxidase positive, urease negative, indole and catalase positive and fermentation of glucose and sucrose were positive while vogous proskaurs, methyl red and $\mathrm{H} 2 \mathrm{~S}$ production were negative. The ability of fermentation of lactose and maltose were negative. Motility in semi-solid agar was negative. Similar results were obtained by Nawaz et al. (2006).

Serological identification of $P$. multocida isolates revealed 7 serotypes ( 5 from lungs, 1 from semen and one untypable isolate). The 5 serotypes from lungs included 4 (A3) and 1 serotype (A1) and the serotype from semen was (A12) (Table 5). Similar results were obtained by Lu and Pakes (1980) and Chengappa et al. (1982) when reported that serotype A12 was the prevalent isolate from domestic rabbits. Moreover, Dabo et al. (1999) reported that pasteurellosis in rabbits is mainly caused by the capsular type A and, to a lesser extent, capsular type D strains However, Jaglic et al. (2008) found that serogroup F was isolated from rabbits.

The results of in vitro antibiotic sensitivity test of $P$. multocida isolates against 19 different antimicrobial agents revealed that $P$. multocida was highly sensitive to thiamphenicole, gentamycin, 
clindamycin, colistin sulphate, tetracycline, enrofloxacin, lincomycin, tetracycline and vancomycin, moderately sensitive to neomycin and oxytetracycline and resistant to ampicillin, erythromycin, penicillin $\mathrm{G}$, sulphamethozole trimethoprim and streptomycin (Table 6). Similarly Herbold et al. (2001) reported that gentamycin was an effective antibacterial drug for the treatment of bacterial genitourinary tract and ciprofloxacin, amoxicillin, amoxycillin + clavulanic acid also effective. Moreover Red Book (2006) reported that amoxicillin-clavulanate was the drug of choice while Balakrishnan and Mini (2001) reported that all $P$. multocida isolates were sensitive to oxytetracycline, pefloxacin and streptomycin. The results revealed that clindamycin and vancomycin had wide inhibitory zone but had adverse effect when used for treatment of rabbits. Similarly, Morris (1995) reported that Ampicillin caused fatal enteritis in rabbits, penicillin caused acute and chronic toxicity (enteritis), cephalexine, tylosin, erythromycin and spectinomycin caused diarrhea, Lincomycin and clindamycin caused high mortalities with enteritis, Vancomycin led to acute toxicity with $100 \%$ mortality, spiramycin led to nervous signs.

P. multocida appeared to be a primary pathogen; indeed, it was possible to induce the experimental infection by challenge with the organisms isolated from apparently healthy rabbit bucks and the clinical signs, macroscopic and microscopic changes of the experimentally infected rabbits were similar to those observed in the naturally infected rabbit bucks.

The result of the present study indicated that $P$. multocida capsular group A, somatic serotype 12 (A:12) played a role in genital pasteurellosis in rabbit bucks which was responsible for low fertility, low reproductivity and the main cause of carrying and spreading of infection among rabbit farms. In the experimental study, $P$. multocida A: 12 was inoculated by intratesticular rout adapted by Riad (2000). The infection

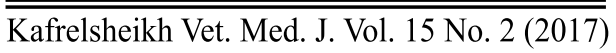


from the outside environment facilitate the entrance of such pathogenic organism indirectly to the testes, this avoided the expected general septicemia which might occur and make the lesion in the examined target organs Selim et al. (2008). P. multocida presents with a variety of clinical symptoms including abseccsses, reproductive infections induced primarily by this microorganism (Kahn, 2005).

The results of the experimental infection of rabbit bucks with $P$. multocida and treatment with mix 3 and thiamphenicole on sperm motility $\%$ were summarized in Table (7). The motility $\%$ on infected groups was significantly decreased when compared with the control groups first two week PI then gradually increased till the end of the experiment. Meanwhile the motility $\%$ was improved in the experimentally infected rabbits groups and treated with mix3, when compare with infected non-treated groups. The improvement remained also better than the self-recovery groups till the end of experiment. Meanwhile, motility $\%$ in the infected groups and treated with thiamphenicole was decreased when compared with infected and treated with mix3. The decrease in motility $\%$ continued till the $5^{\text {th }}$ week then the motility $\%$ improved in last two weeks when compared with infected treated and infected non treated groups then recovered.

The sperm live $\%$ was significantly decreased in the $4^{\text {th }}$ and $5^{\text {th }}$ week in infected non treated groups when compared with the non infected-non treated and infected -treated groups. Moreover the sperm live $\%$ was significantly decreased from the $3^{\text {rd }}-6^{\text {th }}$ week of experiment in the non infected treated groups when compared with the non infectednon treated group.

The sperm concentration was significantly decreased in the first four weeks PI in the infected non treated groups when compared with control group. Moreover the sperm concentration was significantly 
increased in infected-treated groups with mix3, when compared with infected untreated groups. While in the infected group-treated with thiamphenicole, the sperm concentration was significantly decreased till the $5^{\text {th }}$ weeks PI then recovered, when compared with infected treated groups with mix3. The treatment maintained the sperm concentration in the non infected treated groups. Table (7)

The total sperm abnormalities were significantly increased during the five weeks PI in the all infected groups when compared with control group.

The clinicopathological features on intratesticular experimentally infected non treated rabbits (group B) indicated that two rabbit bucks died after 24 hrs. P.I. without any clinical symptoms and the postmortem examination revealed general septicaemic lesions indicated vascular damage as reflected by congestion throughout the carcass. In addition, petechial haemorrhages were observed on pleura, epicardium and subcutenous tissues. The other rabbit bucks of this group showed respiratory manifestations on the $5^{\text {th }}$ day and remained until the bucks were sacrificed at the end of the experiment. Testes of these bucks were enlarged and congested with pustules on the scrotum. Similarly Selim et al. (2008) observed the gross lesions of the experimental rabbit groups subcutaneously infected with $P$. multocida in the scrotum started to appear 3 days P.I. and onwards till the end of experiment at the $7^{\text {th }}$ week with congestion of the inoculated side. Moderate congestion and serous exudates oozed on cut section of lung. Heart appeared congested.

The clinicopathological features on intranasal experimentally infected non treated rabbits (group C) were severe respiratory manifestations included coughing, sneezing and nasal discharges (red nose). Similar findings were reported by Glavits and Magger (1990), and 
Rosell et al. (1992). The sacrificed rabbit bucks showed mild enlargement, congestion and pustules on the scrotum but there were severe pathological changes in the lungs with congested heart. Similar results were recorded by Selim et al. (1998), and Delogn and Manning (1994).

Treatment trials were based on the results of in vitro antibiotic sensitivity test of the isolated $P$. multocida organisms. The clinical signs and postmortem gross lesions disappeared in experimentally intatesticularly and intranasaly infected bucks after treatment with thiamphenicole in drinking water and mixture of gentamycin intramuscular and ciprofloxacine in drinking water for 5 consecutive days when compared with infected untreated control rabbit groups. Similar results were reported by Sinha et al. (2012). Meanwhile Vegad (2012) reported that pencilline, streptomycin, oxtetracycline, chlortetracycline and erythromycin have been used successfully.

Rabbit bucks intratesticularly infected with $P$. multocida and treated with thiamphenicole (group E) and mixture of ciprofloxacine+gentamycin (group D) showed similar clinical symptoms to those of group B (Infected untreated) but the clinical signs and postmortem lesions disappeared on the $5^{\text {th }}$ day of treatment. Intranasal infected rabbit bucks with $P$. multocida and treated with thiamphenicole (group G) and mixture of ciprofloxacine+gentamycin (group F) showed similar clinical symptoms to those of group C (Infected untreated) but the clinical signs and postmortem lesions disappeared on the $5^{\text {th }}$ day of treatment..

Results of histopathological examination of tissue sections in infected untreated Group B revealed that 2 rabbit bucks died after 24 hrs without histopathological findings in the testes but most of lung tissue 
revealed R.B.Cs inside the alveolar lumina and the interstitial tissue, the interalveolar septa appeared to be thickened due to proliferation of septal cells and infiltration of mononuclear inflammatory cells mostly lymphocytes and heterophels were also seen. The lining epithelium of some bronchi and bronchioles showed degenerative changes and/or desquamation into their lumina. Compensatory emphysema was also seen. Heart had no histopathological findings. Similar findings were obtained by Virág et al. (2008). The other three rabbit bucks of this group were sacrificed on the $49^{\text {th }}$ days P.I. and clinical respiratory manifestations were observed on the $5^{\text {th }}$ day P.I and remained until the bucks were sacrificed. Testes revealed focal testicular degeneration represented by depletion of the spermatogonia cells (some semineferous tubules appeared with one to two layers of spermatogonia), moderate hypospermatocytogeneses, thickening of the basement memberane and inhibition of spermiogenesis. Similarly Helen (1995) stated that losses of germinal cells indicated the severity of testicular degeneration. Few tubules appeared atrophied and the interstitial tissue showed thinking due to infiltration of mononuclear cells and fibroblastic proliferation (Fig. 5). Moreover, oedema and congested blood vessels were also seen. Similar findings were observed by Selim et al. (1998). Lungs showed moderate congestion and serous exudates oozed on cut section. Peribronchial and preibronchiolar moderate to severe mononuclear inflammatory cells infiltration together with marked proliferation of bronchus associated lymphoid tissue (BALT) were also seen (Fig.6). Mild hemorrhage (RBCS were seen in some alveoli) and compensatory emphysema was noticed. In addition, the interalveolar septa showed congested blood capillaries and moderated infiltration of lymphocytes and histocytes (Fig.7). Heart revealed pericarditis represented by mild infiltration of mononuclear cells and congestion of the pericardium. Similar findings were reported by Selim et al. (1998). 
Group $\mathbf{C}$ results revealed that two rabbit bucks were sacrificed on the $7^{\text {th }}$ day P.I. Most of the seminefrous tubules (90\%) appeared nearly normal and few tubules showed moderate degeneration in the form of thickening of basement membrane of semineferous tubules and hypospermatogenesis (Fig. 8). R.B.Cs were seen in most of the alveoli and interalveoler septa (Fig.9). Moreover, the alveolar walls appeared to be thickened due to proliferation of septal cells, infiltration of mononuclear inflammatory cells mostly lymphocytes and few heterophiles .The lining epithelium of the bronchi and bronchioles showed degenerative changes and / or desquamation into their lumen (Fig. 10). Compensatory emphysema was also seen. Histopathological changes in heart were similar to those observed in the group B of intratesticular infection with P. multocida but in a mild form. While 49 days P.I. scarification rabbits, histopathological examination of testes revealed nearly similar changes to that observed on the $7^{\text {th }}$ day P.I. in addition to destruction and degeneration in some seminefrous tubules (S.T) were seen (Fig. 11). Lungs showed nearly similar changes to that observed in group B (intratesticular infection) on $49^{\text {th }}$ days P.I. but in a severe form. Mild pericarditis and myocarditis, mild infiltration of lymphocytes and heterophiles and congested blood capillaries were observed in the pericardium and between muscle fibers of the myocardium. Similar findings were obtained by Dziva et al. (2007).

The results of infected and treated groups revealed that the testis in group (E) appeared normal except few tubules had mild degeneration (Fig. 12). The lungs of four rabbit bucks appeared normally to large extent and only one showed thickening of the interstatial tissue due to mononuclear cell infiltration mostly of lymphocytes and severe congestion of the blood capillaries. Compansatory emphysema together 
with congestion of the large blood vessels were also observed. (Fig.13). Hepatic parenchyma showed vacuolar degeneration in most of the hepatocytes together with sporadic necrotized hepatocytes. Mononuclear cell infiltration mostly of lymphocytes and fibrous C.T. proliferation were seen in the portal areas particularly around the bile ducts. In addition activation of Vankupher's cells was also observed (Fig. 14). Most of seminefrous tubules (S.T) in testis of Group (D) appeared normal but some of them had moderate degeneration in the form of decreased number of the spermatogonia cells and thickening of the basement membrane (Fig. 15). Focal areas of moderate thickening of interalveolar septa of lungs due to infiltration of mononuclear cells mostly of lymphocytes were seen. In addition, compensatory emphysema was also noticed. The lesions were seen in the liver of this group were similar to those observed in the rabbit bucks of group E. Histopathological findings noticed in the organs (Testis, lungs and liver) of Group (G) were similar to these observed in the group E, In addition lungs of showed bronchitis but in Group (F) some of the seminefrous tubules (S.T.) appeared normal and the other revealed moderate to severe degeneration (depletion of seprmatogenesis) (Fig. 16). Liver and lungs were similar to those observed in group E. Using thiamphenicole drug gave best results than using mix of ciprofloxacine and gentamycine for treat testis. We thought that routinely used antibiotics made resistance to P. multocida bacterium.

\section{Conclusion:}

Our results revealed that infection of breeding rabbit bucks with $P$. multocida (either intratesticular or intranasal) caused spread of rabbit Pasterullosis and adverse effect on semen parameters. P. multocida infected bucks suffered from decrease in sexual desire. 


\section{ACKNOWLEDGEMENTS:}

Great thanks to Prof. Dr. Hany Abd El-Khalik amer, Professor of Pathology, Pathology department, Animal Reproduction Research Institute and Prof. Dr. Mohamed A. Hassan, Professor of Food Control and Director of Food Analysis Lab, Fac.Vet. Med., Benha University, for their support and help in this work. Also great thanks to all doctors of Artificial Insemination and Embryo Transfer Department at Animal Reproduction Research Institute for their direct supervision and technical support.

Table (1): Primer sequences of $P$. multocida

\begin{tabular}{|c|c|c|c|}
\hline Target gene & Oligonucleotide sequence $\left(\mathbf{5}^{\prime} \rightarrow \mathbf{3}^{\prime}\right)$ & $\begin{array}{c}\text { Product } \\
\text { size (bp) }\end{array}$ & Reference \\
\hline KMT1SP6 (F) & $\mathbf{5}^{\prime}$ GCT-GTA-AAC-GAA-CTC-GCC-AC '3 & \multirow{2}{*}{460} & $\begin{array}{c}\text { Townsend } \\
\text { et al. }(1998)\end{array}$ \\
\cline { 1 - 2 } KMT1T7 (R) & $\mathbf{5}^{\prime}$ ATC-CGC-TAT-TTA-CCC-AGT-GG '3 & & \\
\hline
\end{tabular}

Table (2): Experimental design for infection and treatment of Newzeland White rabbit bucks.

\begin{tabular}{|c|c|c|c|c|c|c|c|}
\hline \multirow[b]{3}{*}{ Groups } & \multirow{3}{*}{$\begin{array}{c}\text { No. } \\
\text { of rabbit } \\
\text { bucks }\end{array}$} & \multicolumn{2}{|c|}{ Saline } & \multirow{2}{*}{\multicolumn{2}{|c|}{ Infected }} & \multirow{2}{*}{\multicolumn{2}{|c|}{ Treatment }} \\
\hline & & \multirow[b]{2}{*}{$\begin{array}{c}\text { Injected } \\
\text { intratesticular }\end{array}$} & \multirow[b]{2}{*}{ Intranasal } & & & & \\
\hline & & & & Intratesticular & Intranasal & $\begin{array}{c}\text { Gentamycin+ } \\
\text { Ciprofloxacine } \\
(\text { mix 3) }\end{array}$ & Thiamphenicole \\
\hline $\mathbf{A}$ & 5 & $\mathbf{S}$ & $\mathbf{S}$ & - & - & - & - \\
\hline B & 5 & $\mathbf{S}$ & & $\mathbf{i}$ & - & - & - \\
\hline $\mathrm{C}$ & 5 & - & $\mathbf{S}$ & - & i & - & - \\
\hline D & 5 & $\mathbf{S}$ & - & i & - & $\mathbf{t}$ & - \\
\hline $\mathbf{E}$ & 5 & $\mathbf{S}$ & - & i & - & - & $\mathbf{t}$ \\
\hline $\mathbf{F}$ & 5 & - & $\mathbf{S}$ & - & i & $\mathbf{t}$ & - \\
\hline $\mathbf{G}$ & 5 & - & $\mathbf{S}$ & - & i & - & $\mathbf{t}$ \\
\hline $\mathbf{H}$ & 5 & $\mathbf{S}$ & $\mathbf{S}$ & - & - & $\mathbf{t}$ & - \\
\hline I & 5 & $\mathbf{S}$ & $\mathbf{S}$ & - & - & - & $\mathbf{t}$ \\
\hline
\end{tabular}

$A=$ Non infected - Non treated group (Controle).

$\mathrm{C}=$ Infected intranasaly with $P$. multocida - untreated group.

$\mathrm{E}=$ Infected intratesticularlly with $P$. multocida treated with Thiamphenicole

$\mathrm{G}=$ Infected intranasaly with $P$. multocida treated with Thiamphenicole.

$\mathrm{I}=$ Non infected treated with Thiamphenicole.
$\mathrm{B}=$ Infected intratesticulary with $P$. multocid $a-$ untreated group.

D = Infected intratesticularlly with $P$. multocida treated with Ciprofloxacine+ Gentamycine.

$\mathrm{F}=$ Infected intranasaly with $P$. multocida treated with Ciprofloxacine+ Gentamycine.

$\mathrm{H}=$ Non infected treated with Ciprofloxacine+Gentamycine

$(-)=$ Not done $(\mathrm{i})=$ infected $(\mathrm{t})=$ treated $\quad(\mathrm{s})=$ saline injected 
Moshira. A. El-Abasy et., al.
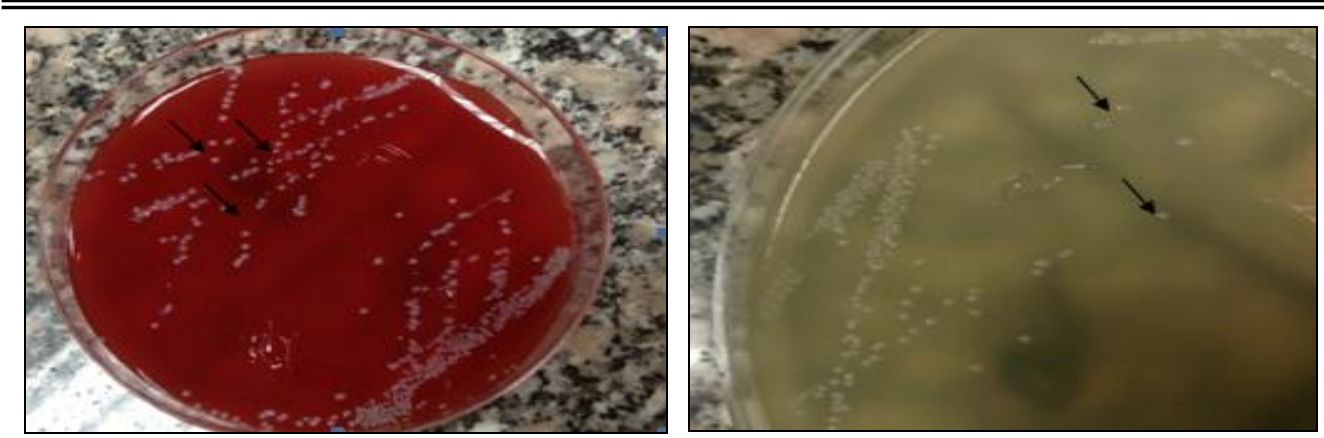

Fig. (1): Colonies of P. multocida on 10\% defibrinated blood agar media showing whitish, smooth, convex and translucent of $0.2-0.5 \times 0.6-$ $2.5 \mu \mathrm{m}$ in diameter after $24 \mathrm{hrs}$. incubation at $37^{\circ}$

Fig. (2): Colonies of P.multocida on dextrose starch agar showing irridesenent about $2 \mathrm{~mm}$ in diameter, and had pearl like appearance after 24 hrs incubation at $37^{\circ} \mathrm{C}$ (black arrows).

$\mathrm{C}$ (black arrows).

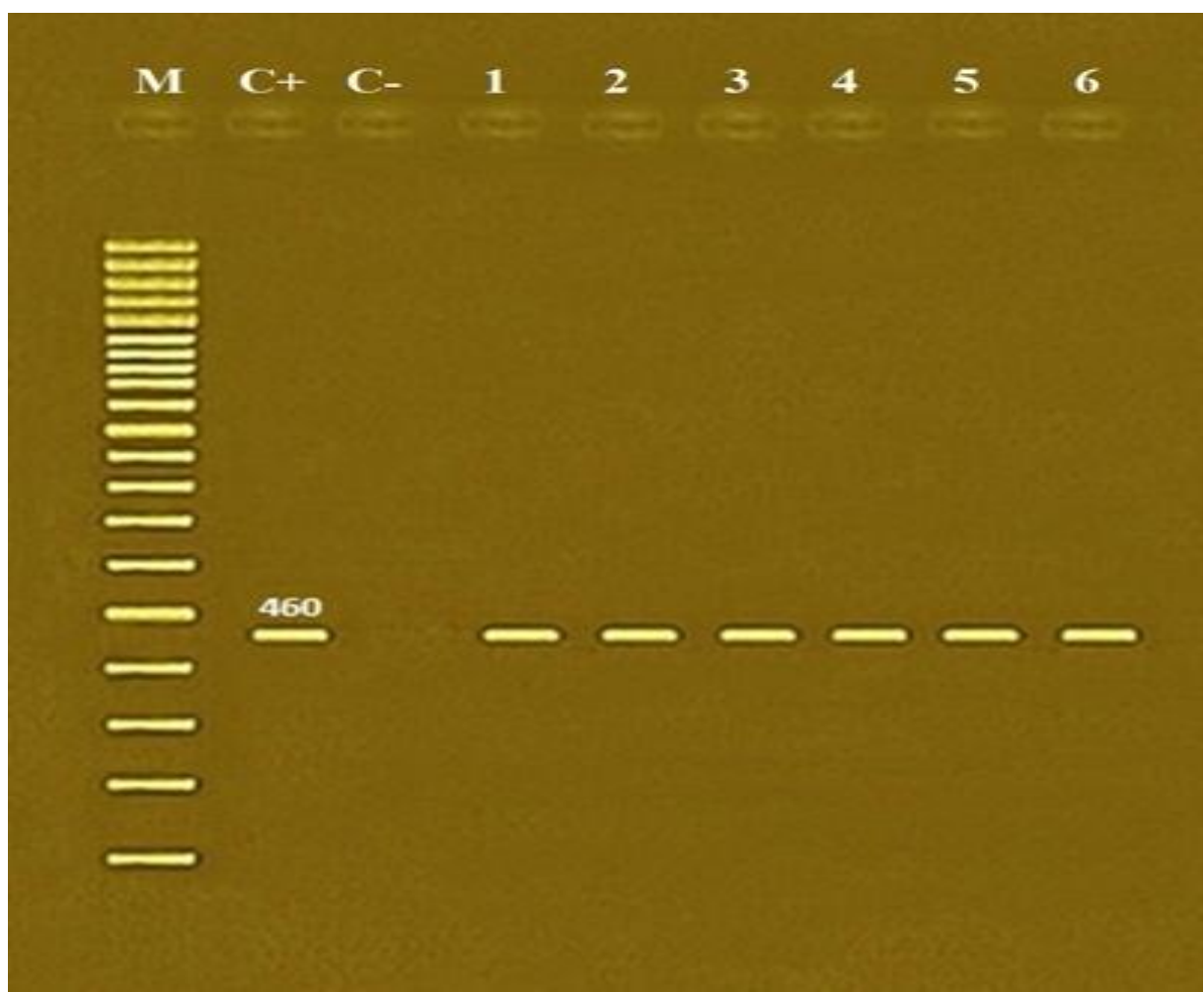

Fig. (3): Agarose gel electrophoresis of PCR amplified product, Lane M; 100 bp ladder as molecular size DNA marker, Lane C+; Control positive P. multocida, Lane C-; Control negative and Lanes 1, 2, 3, 4, 5 and 6; Positive amplification of P.multocida strains (460 bp). Notes: Untypable strain not examined by PCR.

$\overline{\text { Kafrelsheikh Vet. Med. J. Vol. } 15 \text { No. } 2 \text { (2017) }}$ 
Epidemiology And Control Of Genital Pasteurellosis In ...

Table (3): Results of isolation of P. multocida from different rabbit farms at Giza Governorate.

\begin{tabular}{|c|c|c|c|c|c|c|c|c|c|c|c|c|c|}
\hline $\begin{array}{c}\text { Farm } \\
\text { No. }\end{array}$ & $\begin{array}{c}\text { No. of } \\
\text { Rabbit } \\
\text { Flock }\end{array}$ & \begin{tabular}{|c|} 
dead \\
rabbits \\
month
\end{tabular} & $\begin{array}{c}\text { Mortality } \\
(\%)\end{array}$ & $\begin{array}{c}\text { No. of } \\
\text { examined } \\
\text { bucks }\end{array}$ & $\begin{array}{c}\text { No. } \\
\text { of } \\
+ \text { ve }\end{array}$ & $\begin{array}{c}\text { Persentage } \\
\text { of +ve } \\
\text { /flock }\end{array}$ & $\begin{array}{c}\text { Farm } \\
\text { No. }\end{array}$ & $\begin{array}{c}\text { No. of } \\
\text { Rabbit } \\
\text { flock }\end{array}$ & \begin{tabular}{|c|} 
dead \\
rabbits \\
/month \\
\end{tabular} & $\begin{array}{c}\text { mortality } \\
(\%)\end{array}$ & $\begin{array}{c}\text { No. of } \\
\text { examined } \\
\text { bucks }\end{array}$ & $\begin{array}{c}\text { No. } \\
\text { of } \\
+ \text { ve } \\
\end{array}$ & $\begin{array}{c}\text { Persentage } \\
\text { of +ve } \\
\text { /flock }\end{array}$ \\
\hline 1 & 105 & 3 & 2.9 & 6 & - & - & 16 & 90 & 3 & 3.3 & 8 & - & - \\
\hline 2 & 132 & 7 & 5.3 & 10 & - & - & 17 & 98 & 2 & 2 & 7 & - & - \\
\hline 3 & 110 & 3 & 2.7 & 7 & 1 & 0.91 & 18 & 80 & 3 & 3.8 & 9 & - & - \\
\hline 4 & 115 & 5 & 4.3 & 7 & - & - & 19 & 122 & 5 & 4.1 & 8 & 1 & 0.82 \\
\hline 5 & 44 & 2 & 4.5 & 4 & - & - & 20 & 64 & 2 & 3.1 & 3 & - & - \\
\hline 6 & 87 & 3 & 3.4 & 7 & - & - & 21 & 70 & 2 & 2.9 & 8 & - & - \\
\hline 7 & 200 & 5 & 2.5 & 5 & - & - & 22 & 92 & 2 & 2.2 & 4 & - & - \\
\hline 8 & 26 & 1 & 3.8 & 4 & - & - & 23 & 87 & 4 & 4.6 & 7 & - & - \\
\hline 9 & 400 & 5 & 5 & 9 & 2 & 0.5 & 24 & 81 & 4 & 4.9 & 6 & 1 & 1.23 \\
\hline 10 & 75 & 5 & 6.7 & 6 & - & - & 25 & 136 & 7 & 5.1 & 5 & - & - \\
\hline 11 & 118 & 7 & 5.9 & 8 & - & - & 26 & 127 & 5 & 3.9 & 5 & - & - \\
\hline 12 & 79 & 2 & 2.5 & 9 & - & - & 27 & 145 & 6 & 4.1 & 5 & - & - \\
\hline 13 & 107 & 3 & 2.8 & 7 & - & - & 28 & 125 & 4 & 3.2 & 10 & 1 & 0.8 \\
\hline 14 & 146 & 7 & 4.8 & 5 & - & - & 29 & 110 & 5 & 4.8 & 7 & - & - \\
\hline 15 & 73 & 4 & 5.5 & 8 & 1 & 1.37 & 30 & 75 & 4 & 5.3 & 6 & - & - \\
\hline \multicolumn{7}{|c|}{ Total } & 30 & 3319 & 120 & 3.62 & 200 & 7 & 0.21 \\
\hline
\end{tabular}

Table (4): Prevalence of $P$. multocida isolates in various organs and semen of rabbit bucks.

\begin{tabular}{|c|c|c|c|}
\hline Samples & No. of examined samples & No. of isolates & $\begin{array}{c}\text { Rate of Incidence } \\
(\boldsymbol{\%})\end{array}$ \\
\hline Semen & 300 & 1 & 0.33 \\
\hline Testes & 100 & 0 & 0.00 \\
\hline Epididymes & 100 & 0 & 0.00 \\
\hline Lung & 300 & 6 & 2.00 \\
\hline Heart & 100 & 0 & 0.00 \\
\hline liver & 100 & 0 & 0.00 \\
\hline Total & $\mathbf{1 0 0 0}$ & $\mathbf{7}$ & $\mathbf{0 . 7}$ \\
\hline
\end{tabular}

Table (5): Serological identification of $P$. multocida strains.

\begin{tabular}{|c|c|c|}
\hline Key No. & Identified bacterium & Serotypes \\
\hline $\mathbf{1}$ & Pasteurella multocida & A: $\mathbf{3}$ \\
\hline $\mathbf{2}$ & Pasteurella multocida & A: $\mathbf{3}$ \\
\hline $\mathbf{3}$ & Pasteurella multocida & A: $\mathbf{1}$ \\
\hline $\mathbf{4}$ & Pasteurella multocida & $\mathbf{A} \mathbf{3}$ \\
\hline $\mathbf{6}$ & Pasteurella multocida & A: $\mathbf{2}$ \\
\hline $\mathbf{7}$ & Pasteurella multocida & Untypable \\
\hline
\end{tabular}

Kafrelsheikh Vet. Med. J. Vol. 15 No. 2 (2017) 
Moshira. A. El-Abasy et., al.

Table (6): Results of in vitro sensitivity test of P. multocida isolates against 19 different antibacterial agents.

\begin{tabular}{|c|c|c|c|c|c|c|c|}
\hline Serial & & Potancy of & Standard & sensitivity & y zone mm & Cone of inhibatiol & $\mathbf{S} / \mathbf{R}$ \\
\hline No. & Antibacterial agent & $\operatorname{disc}(\mu \mathrm{g})$ & $\mathbf{R}$ & $\mathbf{I}$ & $\mathbf{S}$ & $\mathbf{m m}$ & \\
\hline 1 & Amoxicillin (AML) & 10 & 13 & $14-17$ & 18 & 1.9 & $\mathrm{~S}$ \\
\hline 2 & Amoxycillin + Clavulanic acid (AMC) & 30 & 13 & $14-17$ & 18 & 2.1 & $\mathrm{~S}$ \\
\hline 3 & Ampicillin (AMP) & 10 & 17 & $18-22$ & 23 & 1 & $\mathrm{R}$ \\
\hline 4 & Ciprofloxacin(Cip) & 5 & 15 & $16-20$ & 21 & 2.6 & $\mathrm{~S}$ \\
\hline 5 & Clindamycin (DA) & 2 & 14 & $15-16$ & 17 & 2 & $\mathrm{~S}$ \\
\hline 6 & Colistin sulphate (CT) & 25 & 10 & $12-13$ & 14 & 1.6 & $\mathrm{~S}$ \\
\hline 7 & Enrofloxacin (ENR) & 5 & 16 & $17-20$ & 21 & 2.6 & $\mathrm{~S}$ \\
\hline 8 & Erythromycin (E) & 15 & 12 & $13-15$ & 16 & 0.6 & $\mathrm{R}$ \\
\hline 9 & Gentamycin $(\mathrm{CN})$ & 10 & 12 & $13-14$ & 15 & 2.8 & $\mathrm{~S}$ \\
\hline 10 & Lincomycin (My) & 10 & 14 & $15-20$ & 21 & 2.1 & $\mathrm{~S}$ \\
\hline 11 & Neomycin $(\mathrm{N})$ & 30 & 12 & $13-16$ & 17 & 1.6 & $\mathrm{I}$ \\
\hline 12 & Oxytetracycline (OT) & 30 & 14 & $15-17$ & 18 & 1.5 & $\mathrm{I}$ \\
\hline 13 & Penicillin G (P) & 10 & 21 & $22-28$ & 29 & 1.9 & $\mathrm{R}$ \\
\hline 14 & Spiramycin (SP) & 100 & 16 & $17-19$ & 20 & 1.8 & I \\
\hline 15 & Streptomycin (S) & 10 & 11 & $12-14$ & 15 & 1.4 & $\mathrm{R}$ \\
\hline 16 & Sulphamethozole trimethoprim (SXT) & 25 & 10 & $11-15$ & 16 & 2 & $\mathrm{R}$ \\
\hline 17 & Tetracycline (TE) & 10 & 10 & $11-15$ & 16 & 2.5 & $\mathrm{~S}$ \\
\hline 18 & Thiamphenicole(TP) & 30 & 13 & $14-17$ & 18 & 2.2 & $\mathrm{~S}$ \\
\hline 19 & Vancomycin (VA) & 5 & 6 & $7-14$ & 15 & 1.9 & $\mathrm{~S}$ \\
\hline
\end{tabular}

Table (7): Effect of experimental infection with $P$. multocida on semen evaluation parameters of rabbit bucks.

\begin{tabular}{|c|c|c|c|c|c|c|c|c|c|c|}
\hline $\begin{array}{c}\text { Semen } \\
\text { evaluation }\end{array}$ & days & 7 & 14 & 21 & 28 & 35 & 42 & 49 & $\begin{array}{c}\text { Friedman } \\
\text { chi-squared test }\end{array}$ & $P$ value \\
\hline \multirow{9}{*}{$\begin{array}{c}\text { Sperm } \\
\text { Motility } \\
\%\end{array}$} & $\mathbf{A}$ & 84 & 83 & 81 & 82 & 83 & 83 & 86 & 4.099 & 0.663 \\
\hline & B & 84 & $25+5$ & $36+6.5$ & 58 & 60 & 72 & 73 & 28.659 & $<0.001^{*}$ \\
\hline & C & 85 & $21 \pm 4.1$ & $42 \pm 7.6$ & 62 & 61 & 67 & 76 & 28.517 & $<0.001 *$ \\
\hline & D & 85 & 21 & 46 & 43 & 60 & 62 & 77 & 29.433 & $<0.001 *$ \\
\hline & $\mathbf{E}$ & 86 & 21 & 43 & 40 & 42 & 56 & 73 & 27.444 & $<0.001 *$ \\
\hline & $\mathbf{F}$ & 87 & 27 & 49 & 58 & 71 & 75 & 79 & 28.652 & $<0.001 *$ \\
\hline & $\mathbf{G}$ & 86 & 20 & 34 & 28 & 49 & 64 & 70 & 29.652 & $<0.001^{*}$ \\
\hline & $\mathbf{H}$ & 83 & 80 & 45 & 41 & 30 & 35 & 73 & 28.913 & $<0.001^{*}$ \\
\hline & I & 83 & 81 & 44 & 34 & 36 & 56 & 78 & 27.941 & $<0.001^{*}$ \\
\hline \multirow{9}{*}{ Live /\% } & $\mathbf{A}$ & 88.8 & 90.8 & 91 & 88 & 89.6 & 88.8 & 90.4 & 2.418 & 0.899 \\
\hline & B & 91.8 & 83.4 & 69.6 & 70.2 & 78.8 & 84.8 & 84.6 & 25.319 & $<0.001^{*}$ \\
\hline & $\mathrm{C}$ & 91.4 & 83.6 & 85 & 80.2 & 88.4 & 78.6 & 91.4 & 24.804 & $<0.001^{*}$ \\
\hline & D & 89.4 & 87.4 & 88.2 & 88.6 & 90.6 & 89.6 & 90 & 2.230 & 0.897 \\
\hline & $\mathbf{E}$ & 92.4 & 87.6 & 91.2 & 90.6 & 91 & 90.4 & 91.2 & 9.600 & 0.143 \\
\hline & $\mathbf{F}$ & 91.2 & 89.2 & 89.4 & 89.8 & 91.4 & 90 & 91 & 2.162 & 0.904 \\
\hline & $\mathbf{G}$ & 91 & 86.2 & 88.6 & 88.8 & 91.8 & 90.8 & 90.6 & 8.374 & 0.212 \\
\hline & $\mathbf{H}$ & 90.6 & 89.2 & 84.2 & 80.6 & 74 & 73.4 & 80.2 & 21.054 & $0.002 *$ \\
\hline & I & 90.2 & 89.4 & 66.4 & 70 & 83.6 & 79.2 & 85.8 & 26.496 & $<0.001^{*}$ \\
\hline
\end{tabular}

Kafrelsheikh Vet. Med. J. Vol. 15 No. 2 (2017) 
Epidemiology And Control Of Genital Pasteurellosis In ...

\begin{tabular}{|c|c|c|c|c|c|c|c|c|c|c|}
\hline $\begin{array}{c}\text { Semen } \\
\text { evaluation }\end{array}$ & Groups & 7 & 14 & 21 & 28 & 35 & 42 & 49 & $\begin{array}{c}\text { Friedman } \\
\text { chi-squared test }\end{array}$ & $P$ value \\
\hline \multirow{9}{*}{$\begin{array}{c}\text { Concentration } \\
\text { X } 10^{6} / \mathrm{ML}\end{array}$} & A & 357 & 373 & 361 & 359 & 361 & 371 & 359 & 2.759 & 0.838 \\
\hline & B & 373.6 & 283 & 255.2 & 218.8 & 296.2 & 370 & 353.6 & 26.763 & $<0.001 *$ \\
\hline & $\mathrm{C}$ & 293.6 & 184.2 & 138.4 & 174.8 & 168 & 254.4 & 258.4 & 23.525 & $<0.001 *$ \\
\hline & D & 383.2 & 312.2 & 293.2 & 277 & 354.4 & 361.8 & 372.2 & 24.686 & $<0.001 *$ \\
\hline & $\mathbf{E}$ & 381.6 & 203.8 & 212.8 & 261 & 305.6 & 391 & 362.2 & 27.857 & $<0.001^{*}$ \\
\hline & $\mathbf{F}$ & 349.4 & 298.4 & 283.2 & 285.6 & 349 & 361.6 & 382.6 & 20.657 & $0.002 *$ \\
\hline & $\mathbf{G}$ & 366 & 289.2 & 282.8 & 254.6 & 268.8 & 268 & 388.2 & 21.820 & $0.001 *$ \\
\hline & $\mathbf{H}$ & 322.6 & 325.2 & 334 & 337 & 347.4 & 324 & 323.2 & 3.391 & 0.789 \\
\hline & I & 363.6 & 350 & 335.8 & 343.6 & 344.2 & 340.2 & 334.4 & 3.391 & 0.758 \\
\hline \multirow{9}{*}{$\begin{array}{c}\text { Total } \\
\text { sperm } \\
\text { abnormalities }\end{array}$} & $\mathbf{A}$ & 8.6 & 8.6 & 6.8 & 8.4 & 8 & 8.8 & 9.4 & 5.386 & 0.495 \\
\hline & B & 8.4 & 24.8 & 20.6 & 13.6 & 13 & 14.4 & 10.6 & 24.087 & $0.001 *$ \\
\hline & $\mathrm{C}$ & 9.4 & 18 & 12.2 & 13 & 16.6 & 9.8 & 9.8 & 18.047 & $0.006^{*}$ \\
\hline & D & 9.8 & 22 & 24.8 & 25.8 & 26.2 & 14 & 12.8 & 23.149 & $0.001 *$ \\
\hline & $\mathbf{E}$ & 5.2 & 21 & 15.4 & 17.8 & 10.8 & 9.6 & 10.4 & 24.044 & $0.001 *$ \\
\hline & $\mathbf{F}$ & 8.4 & 24.8 & 15.2 & 16.8 & 14.8 & 9 & 9 & 23.804 & $0.001 *$ \\
\hline & $\mathbf{G}$ & 4 & 10 & 14.4 & 12.6 & 17.8 & 12.8 & 10.4 & 19.787 & $0.003^{*}$ \\
\hline & $\mathbf{H}$ & 6.8 & 7 & 8.2 & 12.8 & 33.6 & 25.4 & 13.2 & 26.562 & $<0.001 *$ \\
\hline & I & 8.4 & 7.8 & 10.2 & 13.8 & 35.6 & 14.2 & 9.4 & 24.982 & $<0.001 *$ \\
\hline
\end{tabular}

$A=$ Non infected - Non treated group (Controle).

$\mathrm{C}=$ Infected intranasaly with $P$. multocida - un treated group.
$\mathrm{B}=$ Infected intratesticulary with $P$. multocida - Non treated group.

$\mathrm{D}=$ Infected intratesticularly with $P$. multocida treated with Ciprofloxacine+ Gentamycine.

$\mathrm{E}=$ Infected intratesticularlly with $P$. multocida treated with $\mathrm{I}=$ Uninfected treated with Thiomphenicole.

Thiomphenicole .

$\mathrm{F}=$ Infected intranasaly with $P$. multocida treated with $\mathrm{G}=$ Infected intranasaly with $P$. multocida treated with Ciprofloxacine+ Gentamycine.

$\mathrm{H}=$ Uninfected treated with Ciprofloxacine+Gentamycine.

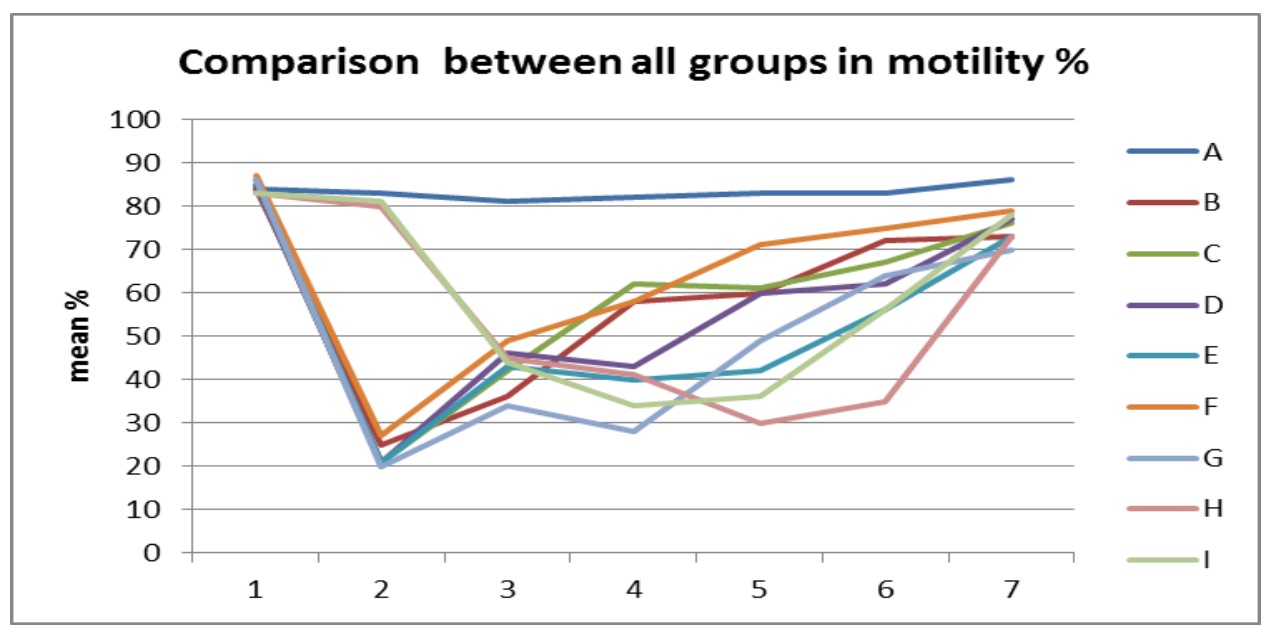

Kafrelsheikh Vet. Med. J. Vol. 15 No. 2 (2017) 
Moshira. A. El-Abasy et., al.
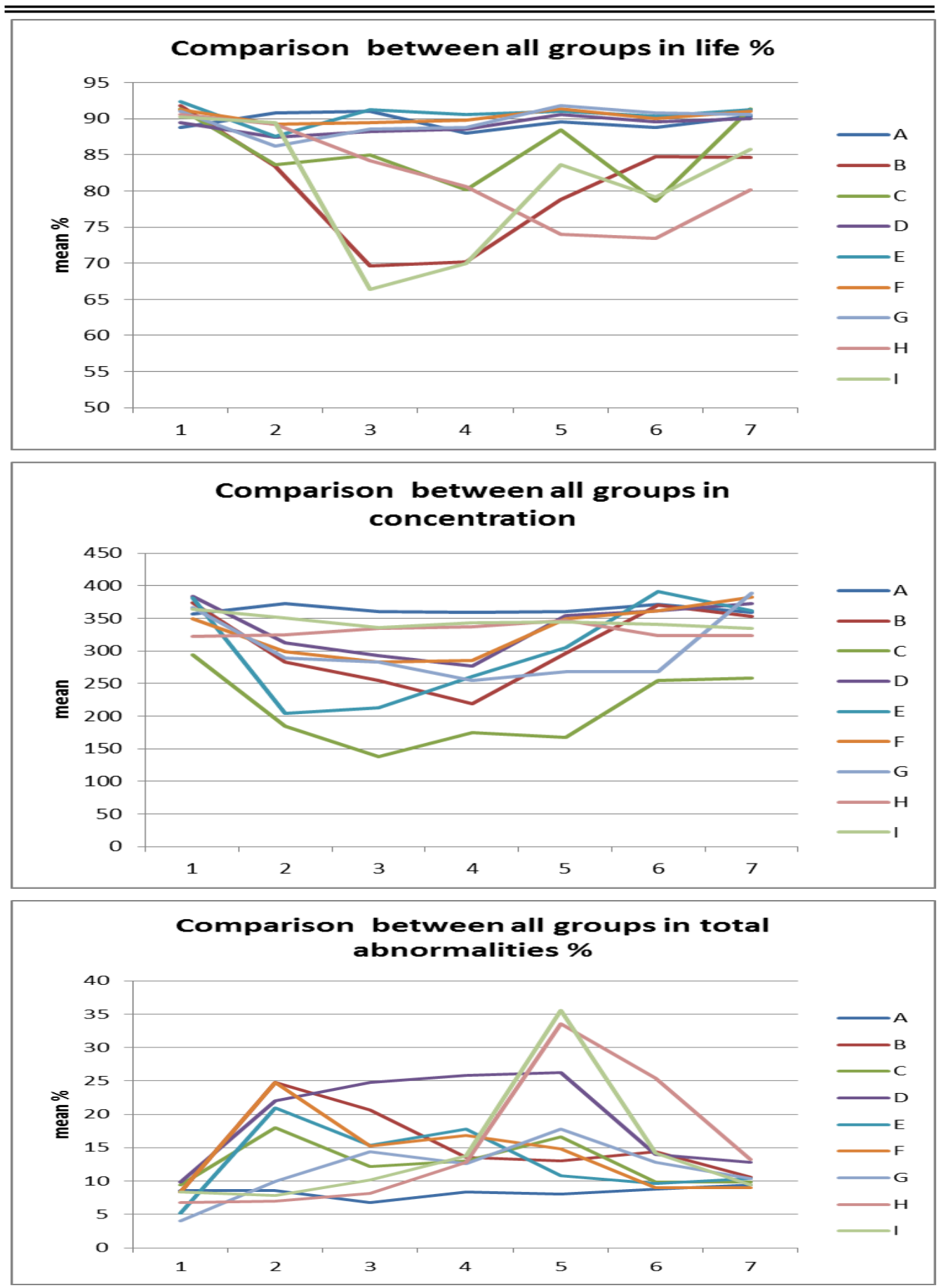

$\overline{\text { Kafrelsheikh Vet. Med. J. Vol. } 15 \text { No. } 2 \text { (2017) }}$ 
Fig. (4): Effect of experimental infection with $P$. multocida on sperm parameters.

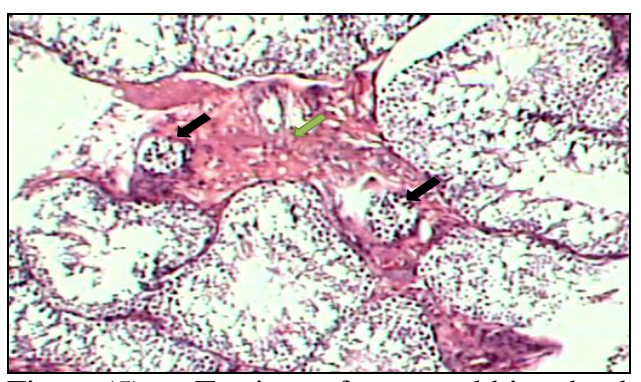

Fig. (5): Testis of a rabbit buck intratesticularly infected with $P$. multocida; sacrificed after 49 days P.I. showed atrophied tubules (black arrows) and thickening of the interstitial tissue due to infiltration of mononuclear cell and fibroblastic proliferation (green arrow) $(\mathrm{x} 40)$

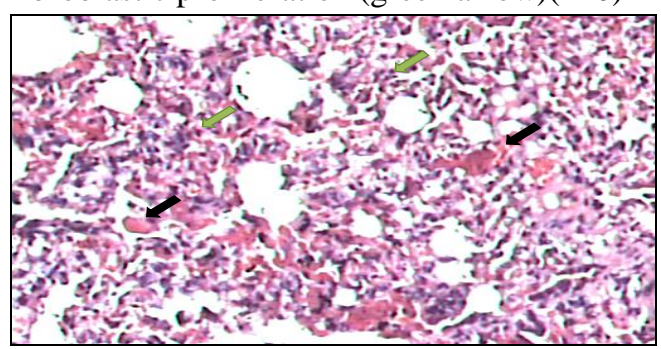

Fig. (7) Lungs of a rabbit buck intratesticularly infected with $P$. multocida; sacrificed after 49 days P.I. showed congestion in the blood capillaries (black arrows) and moderate infiltration of lymphocytes and histocytes in the interalveolar septa (green arrows) (X100).

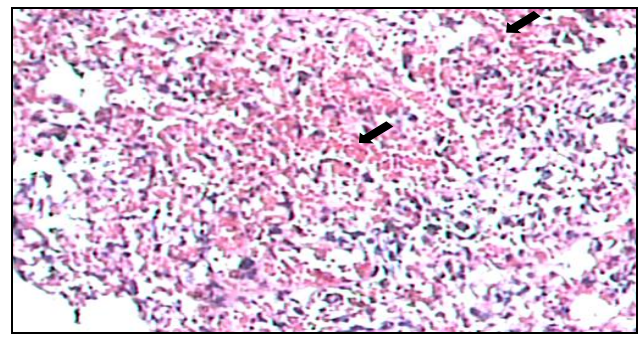

Fig. (9) lungs of a rabbit buck intranasaly Fig. (10): lungs of a rabbit buck intranasaly infected with $P$. multocida; sacrificed after 7 infected with $P$. multocida; sacrificed after 7 days P.I. showed R.B.Cs inside the alveolar days P.I. showed degenerative change and / or lumina and the interstitial tissue (X 100)

$\overline{\text { Kafrelsheikh Vet. Med. J. Vol. } 15 \text { No. } 2 \text { (2017) }}$

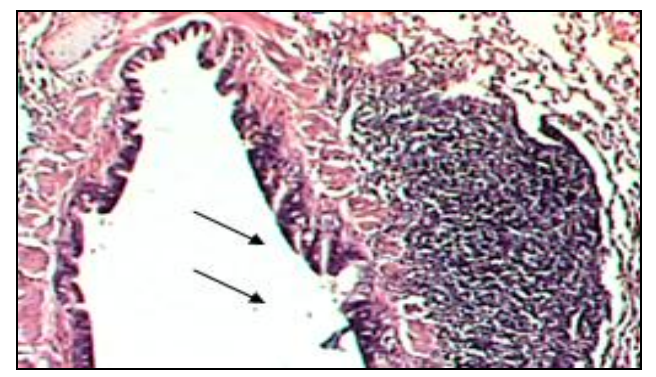

Fig. (6): Lungs of a rabbit buck intratesticularly infected with P. multocida; sacrificed after 49 days P.I. showed proliferation BALT (black arrows) (x40).

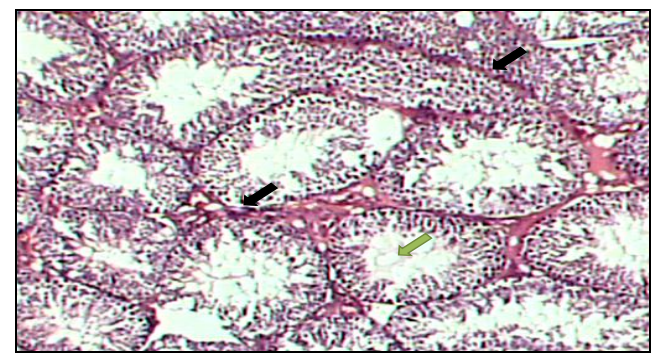

Fig. (8): Testes of a rabbit buck infected intranasaly with $P$. multocida; sacrificed after 7 days P.I. showed moderate degeneration in the form of thickening of basement membrane of S. T. (black arrows) and hypospermatogenesis (green arrows) (X40)

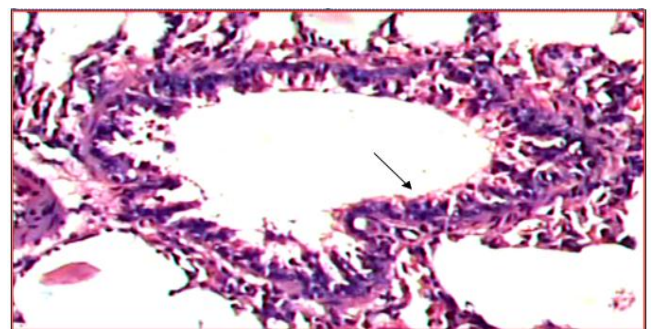
desquamation of lining epithelium of the bronchiole (x 100). 
Moshira. A. El-Abasy et., al.

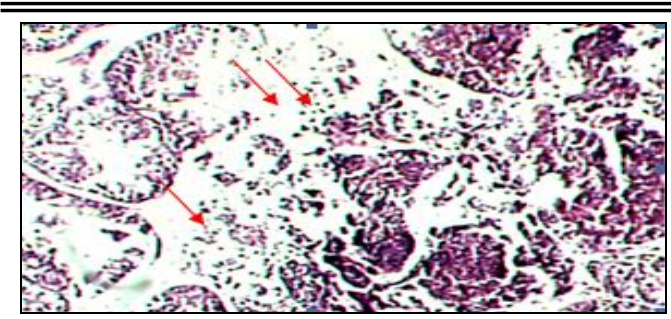

Fig. (11): Testes of a rabbit buck infected intranasaly with $P$. multocida; sacrificed after 49 days P.I. showed destruction and degeneration in some S.T. (red arrows) (x40).

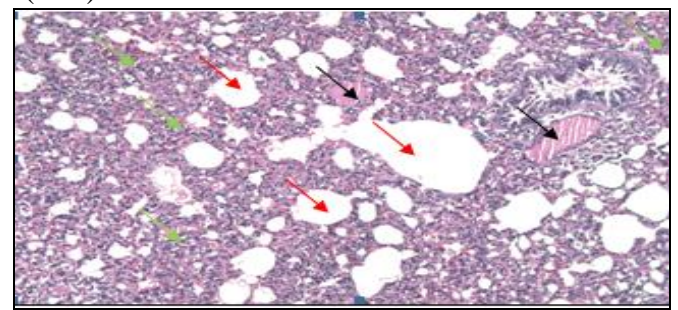

Fig. (13) Lungs of a rabbit buck sacrificed after 49 days P.I. intratesticularly with $P$. multocida; and treated with thiamphenicole (group E), showed infiltration of mononuclear cells mostly of lymphocytes in the interalveolar septa (green arrows), severe congestion of the blood capillaries and B.vs (black arrows) and compensatory emphysema (red arrows) (x4).

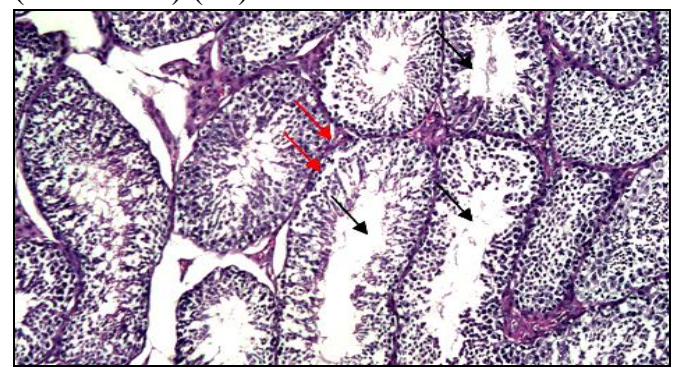

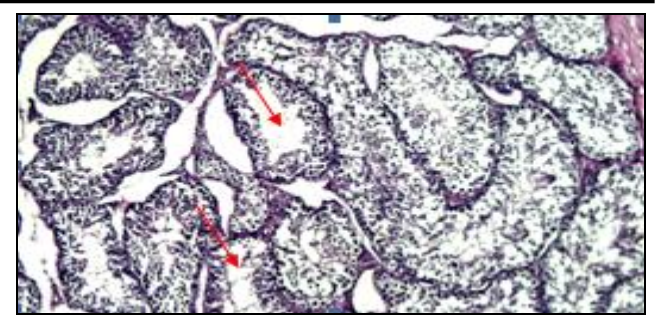

Fig. (12): Testis of a rabbit buck sacrificed after 49 days P.I. intratesticularly with $P$. multocida; and treated with thiamphenicole (group E), showed mild degeneration in the S.F. tubules (red arrows) (x 100).

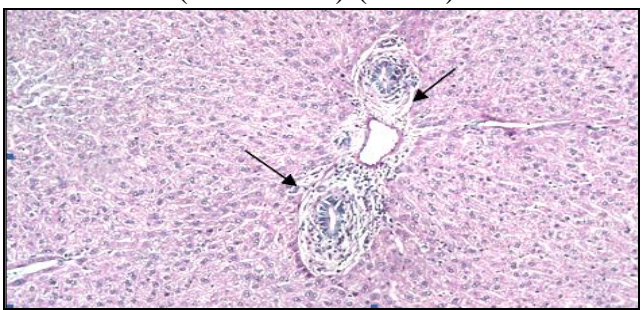

Fig. (14): Liver of a rabbit buck sacrificed after 49 days P.I. intratesticularly with $P$. multocida; and treated with thiamphenicole (group E), showed infiltration of mononuclear cells mostly of lymphocytes and fibroblastic proliferation around the bile duct in the portal areas (black arrows) (x 4).

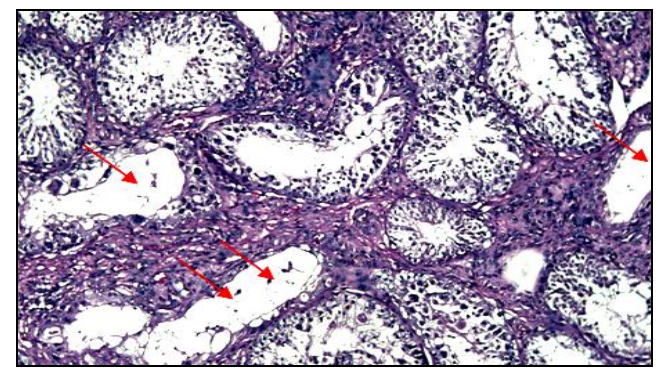

Fig. (15): Testis of a rabbit buck sacrificed Fig. (16): Testis of a rabbit buck sacrificed after 49 days P.I. intratesticularly with $P$. after 49 days P.I. airosolaly with $P$. multocida; multocida; and treated with ciprofloxacine + and treated with mixture of ciprofloxacine + gentamycin (group D), showed decreased gentamycin (group F), showing moderate to number of spermatogonia cells (black arrows) severe degeneration in the S.T. (depletion of and thickening of the basement membrane of spermatogenesis) (red arrows) (X100). the S.T.(red arrows) (X100).

$\overline{\text { Kafrelsheikh Vet. Med. J. Vol. } 15 \text { No. } 2 \text { (2017) }}$ 


\section{REFERENCES}

- Abd El-Ghaffar, N. EL-S. (1992): Some studies on the artificial insemination in rabbit. Ph.D. Thesis, Faculty of Vet. Med. Zagazig Univ. (Banha).

- Antony, P., Nair, G., Jayaprakasan, V., Mini, M. and Aravindakshan, T. (2007): Nucleic acid based differentiation of Pasteurella multocida serotypes. The Internet J. Vet. Med., 2 (2): 85-89.

- Ashraf, A., Mahboob, S., Al-Ghanim, K, Huma, T. and Shah, M. S. (2014): Immuogenic activity of lipopolysaccharides from Pasteurella multocida in rabbits. JAPS, Journal of Animal and Plant Sciences, 24 (6): 1780-1785.

- Balakrishnan, G., and Mini, M., (2001): Plasmid profile and antibiotic resistance pattern of $P$. multocida of avian origin. Indian Vet. J., 78: $783-786$.

- Bancroft, J. D. and Stevens, A. (1990): Theory and practice of Histological Techniques.Third edition, New York.

- Calnek, B. W., Barnes, H. J., Beard, C.W., McDougald, L. R. and Saif, Y. M. (1997): Diseases of poultry. $10^{\text {th }}$ edn., Iowa State University Press, Ames, Iowa, U.S.A.

- Casalinuovo, F., Tucci, A. and Battaglia, L. (2013): Control of disease of reproductive Pasteurella spp rabbit. Journal Large Animal Review Vol. 19 No. 6 pp: 271-274. 
- Chengappa, M. M., Myers, R. C. and Carter, G. R. (1982): Capsular and somatic types of Pasteurella multocida from rabbits. Canadian Journal of Comparative Medicine-Revue Canadienne de Medecine Comparee, 46: 437- 439.

- Cruickshank, R. J. Dugaid, P., Marmion, B. P. and Swain, R. H. A. (1975): Medical Microbiology, $12^{\text {th }}$ Ed, Living stone L.T.D, Edinburgh, London, New York.

-Dabo, S. M., Confer, A. W., Montelongo, M., Lu, Y. S. (1999): Characterization of rabbit Pasteurella multocida isolates by use of whole-cell, outer-membrane, and polymerase chain reaction typing. Laboratory Animal Science, 49: 551-559.

- Delong, D. and Manning, P. J. (1994): Bacterial diseases. In: Manning P.J., Ringler D.H., Newcomer C.E. (eds.): TheBiology of the Laboratory Rabbit. 2nd ed. Academic Press, Inc., San Diego: 129-170.

- Dziva, F., Muhairwa, A., Bisgaard, M. and Christensen, H. (2007): Diagnostic and typing options for investigating diseases associated with Pasteurella multocida, Vet. Microbiology, vol. 128 no. 1-2, pp. 1-22.

- El-Tayeb A.B., Morishita T. Y. and Angrick E. J. (2004): Evaluation of Pasteurella multocida isolated from rabbits by capsular typing, somatic serotyping and restriction endonuclease analysis. Journal of Veterinary Diagnostic Investigation, vol. 16, no. 2, pp. 121-125.

- Evans, G. and Maxwell, W. M. C. (1987): Salmons artificial insemination of sheep and goats. Buterwarths pty limited, Australia. 
- Glavitis R. and Magyar, T. (1990): The pathology of experimental respiratory infection with Pasteurella multocida and Bortettella bronchiseptica in rabbits. Acta veterina Hungarica, 38 (3): 211-215.

- Glisson, J. R., Hofacre, C. L. and Christensen, J. P. (2003): Fowl cholera. In Diseases of Poultry, PP: 658-676.

- Heddleston, K. L., Gallagher, J. E. and Rebers, P.A (1972): Fowl cholera gel diffusion precipitin test for serotyping Pasteurella multocida from avain species. Avian Dis. 16: 925-9.

- Helen, M. A. (1995): Thomsons Special Vet. Path. $2^{\text {nd }}$. Ed, Published by MERK \& Co. INC, USA.

- Herbold, B.A., Brendler- Schwaab S.Y. and Ahr H.J. (2001): Ciprofloxacin: In vivo genotoxicity studies. Mutat. Res., 498: 193-205.

- Jaglic, Z., Jeklova, E., Leva, L., Kummer, V., Kuccerova, Z., Faldyina, M., Maskova, J.; Nedbalocova, K. and Alexa, P. (2008): Experimental study of pathogenicity Pasteurella multocida serogroup F in rabbits. Vet. Microbiol. 1, 126 (1-3): 168-177.

- Kahn, C. M. (2005): The Merk Veterinary Manuak, 9 th ed. Published by MERK \& Co. INC, USA.

-Kuster, C. E. and Althouse, G. C. (2016): The impact of bacteriospermia on boar sperm storage and reproductive performance. Theriogenology. 85 (1): 1-172.

- Lebdah (2010): Hand Book of Rabbit Medicin. PP: 45-55.

-Lee, M. D., Glisson, J. R., Wooley, R. E., Brown, J. (1990): Characterization of Pasteurella multocida mutants of low virulence. Avian Diseases, 34:958-963. 
- Lee, M. D., Wooley, R. E., Brown, J., Glisson, J. R. (1991): A survey of potential virulence markers from avian strains of Pasteurella multocida. Veterinary Microbiology, 26: 213-225.

-Lu, Y. S. and Pakes, S. P. (1980): Protection of rabbits against experimental Pasteurellosis by a streptomycin-dependent Pasteurella multocida serotype 3: A Live mutant vaccine. Infect Immune 34: 1018-1024.

- Mercier, P. and Rideaud P. (1992): Bacteriological study of rabbit sperm and the effects of antibiotic supplements in the conservation medium. J. Appl. Rabbit Res., 15: 520-529.

-Morris, T. H. (1995): Antibiotic therapeutics in laboratory animals. Laboratory Animals.29: 16-36.

- Nada, H. S. (1994): Isolates in rabbits serological types and experimental infection. Vet. Med. J. Giza 42(3): 73-77.

- Nawaz, I., Munlr, R., Farooq, U., Kausar, R. and Khanum, A. (2006): Whole cell protein profiling of Pasteurella multocida field isolates in Pakistan, Pakistan Veterinary journal. 26 (4):157-168.

- Red Book (2006): Report of the Committee on Infectious Diseases 27th Ed.

- Riad Rowida, R. M. (2000): Effect of seminal bacterial pathogens on rabbit bucks performance $\mathrm{Ph}$. D. Faculty of V. Med. Cairo University.

- Reynolds, A., Thomas, W., Wilson, W. and Oliphant, G. (1989): Concentration of Acrosome stabilizing Factor (ASF) in rabbit epididymal fluid and species specificity of Anti-ASF. Antibodies. Biol. of Reprod. 40: 673-680. 
- Rendondo, E, Roncero, V., Masot, A. J. and Duran, E. (1990): Experimental rabbit pneumonic pasteurellosis. Acta Medica Vet., 36 (1): 3-20.

- Rhoades, K. $\boldsymbol{R}$ and Rimler, R. B. (1987): Effects of Pasteurella multocida endotoxins on turkey poults. Avian Diseases, 31: 523-526.

- Rosell, J. M., Badiola, J. I., Delafuente, L. F., Carmenes, P. and Badiola, J. J. (1992): Rhinitis of the domestic rabbit. An epidemiological survey during the period 1986-1991. I. Influence of the year, season and type of rabbitry. J. Appl. Rabbit Res. 15:1375-1381.

- Selim, S. A; AmaL, A. M. Ghoneim; Dokhan, KH. Z. and Rowida, M. Riad (2008): Role of Pseudomonas Aeruginosa and Pasteurella multocida on semen characteristics of rabbit bucks and their pathological effects. Assiut Vet. Med. J. Vol. 54 No. 119.

- Selim, S. A., Rabie, N. S., Bassiony, M. M. and Ibrahim, I. G. (1998): Bacteriological and Histopathological studies on pyogenic endometritis in rabbits. J. Egypt Ger. Soc. Zool., 26: 59-69.

- Sinha, C., Yadav, S., Brijesh Yadav, B. and Singh, K. (2012): Effects of Enrofloxacin Administration on Semen Quality of Barbari bucks. Advanced Vet. Research J. Vol. 2 : 179-183.

- Townsend, K., Frost, A., Lee, C., Papadimitriou, J. and Dawki (1998): Development of PCR assays for species- and type-specific identification of Pasteurella multocida isolates. J. Clin. Microbiol. 16:1096-1100.

- Vegad, J. L. (2012): Poultry Diseases. Second Revised and Enlarged Edition. Textbook. PP: 153-156.

- Virág, G. y., Kulcsár, G. and Makranszki, L. (2008): Mice pathogenicity of Pasteurella multocida strains isolated from diseased and healthy rabbits. $9^{\text {th }}$ World Rabbit Congress-June 1013.Verona-Italy. 
وبائية و طرف السيطرة على عدوى الباستيريلا التناسلية فى أرانب التربية

مشيرة العباسى "أمانى طه" "، رويدا رياض "، أمال غنيم" "، عبد الجليل الجوهرى"

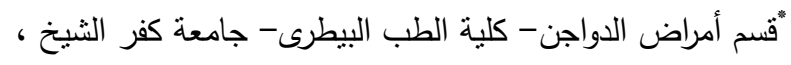

$$
\begin{aligned}
& \text { "قسم التلقيح الاصطناعى و نقل الأجنة - معهد تتاسليات الهرم - الجيزة ، }
\end{aligned}
$$

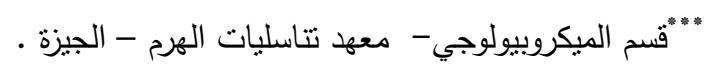

الهدف من البحث دراسة وبائية و طرق السيطرة على عدوى الباستيريلا مالتوسيدا كمسبب لعدوى

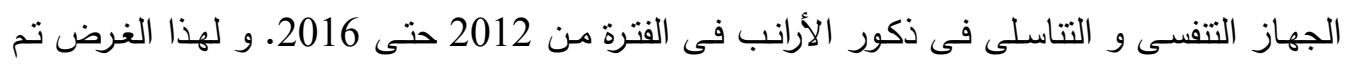
الفحص البكتيريولوجى للعينات المجمعة من 200ذكور أرانب نتبدو ظاهريا سليمة و نتراوح أعمارهم

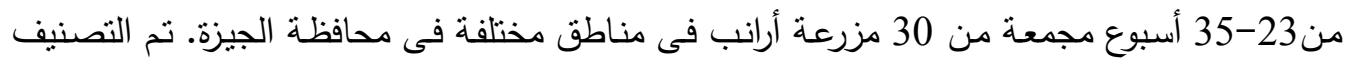

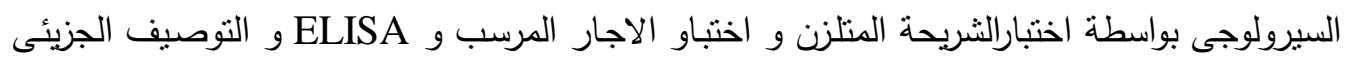

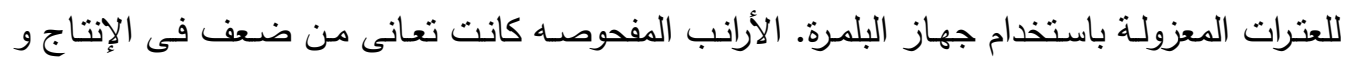

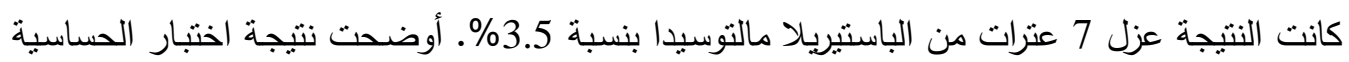

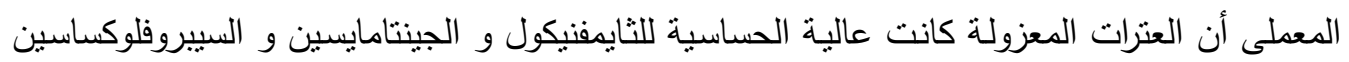

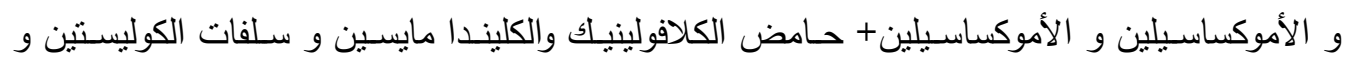
التتراسيكلين و الإنروفلوكساسين و اللينكومايسين و الفانكومايسين و أنها متوسطة الحساسية للنيومايسين

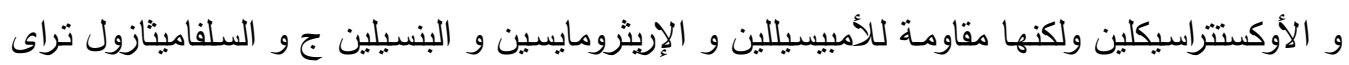

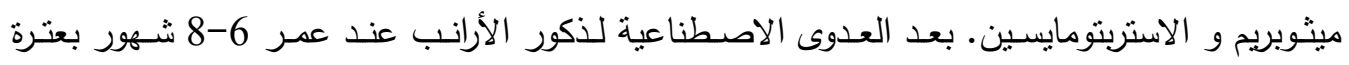

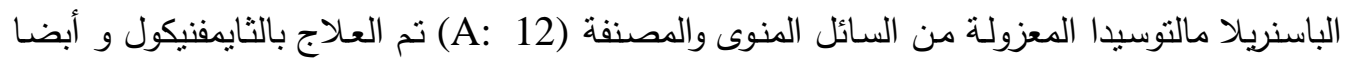
بالجينتامايسين مع السيبروفلوكساسين. تم مناقثتهم الأعراض الإكلينيكية و الصفة التشريحية و تقييم

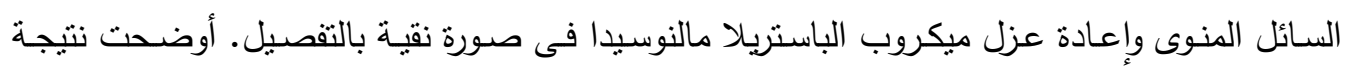
الفحص الهستوباثولوجى لثرائح رقيقة من الأعضاء الداخلية المختلفة لذكور الأرانب المعدية صناعيا

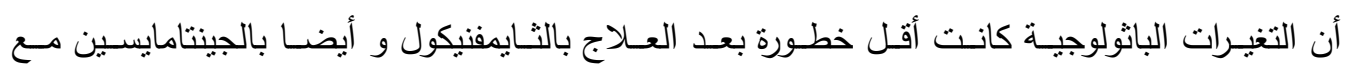

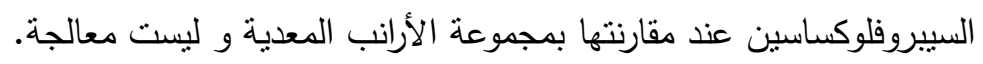

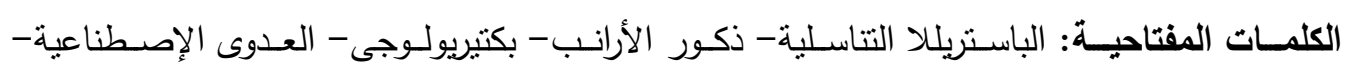

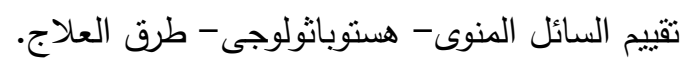

